\title{
PEMBELAJARAN PENDIDIKAN ANTI KORUPSI MELALUI PENDIDIKAN AGAMA ISLAM
}

\author{
Suniti \\ IAIN Syekh Nurjati Cirebon \\ sunitimunir@gmail.com
}

\begin{abstract}
ABSTRAK
Saat ini korupsi oleh banyak negara telah dipandang sebagai sebuah kejahatan luar biasa (extra ordinary crime) karena dampak sistemik yang ditimbulkan oleh tindakan korupsi. Indonesia sebagai Negara berkembang juga menghadapi persoalan korupsi yang menyentuh hampir seluruh sendi kehidupan. Upaya memberantas korupsi yang dianggap efektif dan murah adalah melalui pendidikan. Bidang pendidikan merupakan salah satu upaya preventif terbaik yang bisa dilakukan. Misalnya melalui Pendidikan Anti Korupsi dan menanamkan nilainilai integritas pada anak sejak dini. Adapun pendekatan yang digunakan dalam penelitian ini adalah pendekatan deskriptif kualitatif.

Hasil penelitian ini menunjukkan bahwa guru pendidikan Agama Islam dan siswa di SMK Al-Hidayah Cirebon yang berbasis pesantren, telah memahami pengertian dari korupsi dan bentuk-bentuknya. Materi Pendidikan Agama Islam yang dapat diintegrasikan dengan Pendidikan Anti Korupsi antara lain : Memahami Makna Jujur, Pengertian Jujur, Pembagian Sifat Jujur, Ayat-Ayat Al-Qur'an dan Hadits Tentang Perintah Berlaku Jujur. Dalam proses pembelajaran menggunakan Model Integrasi dengan metode social learning dan role playing. Hasil dari penelitian diharapkan dapat meningkatkan penerapan prilaku nilai-nilai pendidikan anti korupsi dalam perilaku sehari-hari.
\end{abstract}

Kata Kunci : Model Pembelajaran, Pendidikan Agama Islam, Pendidikan Anti Korupsi

\section{ABSTRACT}

Currently, corruption by many countries has been viewed as an extraordinary crime because of the systemic impact caused by acts of corruption. Indonesia as a developing country also faces the problem of corruption that touches almost all aspects of life. Efforts to eradicate corruption that are considered effective and inexpensive are through education. The education sector is one of the best preventive measures that can be done. For example, through Anti-Corruption Education and instilling integrity values in children from an early age. The approach used in this research is a qualitative descriptive approach.

The results of this study indicate that Islamic religious education teachers and students at the Islamic boarding school-based Vocational School Al-Hidayah Cirebon have understood the meaning of corruption and its forms. Islamic Religious Education materials that can be integrated with Anti-Corruption Education include: Understanding the Meaning of Honest, Understanding Honest, Sharing of Honest Traits, Al-Qur'an Verses and Hadith About the Commandment to Be Honest In the 
learning process using an Integration Model with social learning and role playing methods. The results of the research are expected to improve the application of anticorruption educational values in daily behavior.

Keywords: Islamic Religion Education, Anti-Corruption Education, Learning Models.

\section{A. PENDAHULUAN}

Korupsi oleh dunia internasional telah dipandang sebagai sebuah kejahatan luar biasa (extra ordinary crime) karena dampak sistemik yang ditimbulkan oleh tindakan korupsi. Hal ini kemudian mendorong masyarakat internasional memikirkan upaya bersama menciptakan tata kelola pemerintahan Negara-negara di dunia yang lebih bersih dan transparan. Upaya tersebut kemudian diwujudkan melalui United Nations Convention Against Corruption (UNCAC) yang telah ditandatangani oleh lebih dari 140 negara dan dilakukan penadatanganan pertama kali pada konvensi internasional yang diselenggarakan di Mérida, Yucatán, Meksiko, pada tanggal 31 Oktober 2003 (KPK: 2021).

Sebuah Negara dikategorikan sebagai Negara yang kuat dan maju apabila tata kelola pemerintahan berlangsung dengan bersih dan transparan, sebaliknya sebuah Negara dikategorikan sebagai Negara berkembang apabila korupsi masih menjadi bagian dari budaya dan kebiasaan masyarakat (Wibowo:2010). Semakin tinggi level korupsi sebuah Negara maka semakin lemah Negara tersebut.. Indonesia sebagai Negara berkembang juga menghadapi persoalan korupsi yang menyentuh hampir seluruh sendi kehidupan, bahkan disebut telah menjadi budaya dan kebiasaan. Berdasarkan laporan indeks persepsi korupsi (Corruption Perception Index (CPI) 2019 yang diterbitkan secara global oleh Transparency International (TI) masih menempatkan Indonesia sebagai negara dengan level korupsi yang tinggi. Survei tersebut memperlihatkan korupsi secara khusus disebut menempati urutan teratas dari 18 (delapan belas) faktor penghambat kemudahan berusaha di Indonesia. Transparency International sendiri adalah organisasi masyarakat sipil global yang berada di garis terdepan dalam upaya perlawanan terhadap korupsi. Melalui lebih dari 90 perwakilan di seluruh dunia dan satu sekretariat internasional di Berlin, TI membangun kesadaran mengenai dampak buruk 
korupsi dan bekerja sama dengan mitra kerja di Pemerintah, Perusahaan dan Masyarakat Sipil dalam rangka mengembangkan dan melaksanakan langkahlangkah yang efektif untuk mengatasi masalah tersebut.

Survei yang juga dilakukan oleh Political and Economy Risk Consultancy (PERC), sebuah perusahaan konsultan bisnis yang berbasis di Hongkong juga mengeluarkan hasil studi tahunannya tentang tingkat korupsi di negara-negara tujuan investasi di kawasan Asia Pasifik. Dari 16 negara (14 Negara Asia, Amerika Serikat dan Australia) yang disurvei, Indonesia dikategorikan sebagai negara paling korup setelah Vietnam, diikuti India, Kamboja, Filipina, Cina, Thailand, Korea Selatan, Taiwan, Amerika Serikat Malaysia, Taiwan, Korea Selatan, Macao, Hong Kong, Australia, Jepang dan Singapura. Skor Indonesia 8,09 dalam skala 0-10, di mana 0 berarti sangat bersih, dan 10 sangat korup. Survei tahun 2015 dilakukan PERC terhadap responden eksekutif bisnis tingkat menengah dan senior di Asia, Australia, dan Amerika Serikat.

Survei-survei yang dilakukan lembaga-lembaga internasional tersebut memperlihatkan korupsi yang terjadi di Indonesia sudah sangat mengkhawatirkan dan berdampak buruk luar biasa pada hampir seluruh sendi kehidupan. Korupsi telah menghancurkan sistem perekonomian, sistem demokrasi, sistem politik, sistem hukum, sistem pemerintahan, dan tatanan sosial kemasyarakatan di negeri ini. Dilain pihak upaya pemberantasan korupsi yang telah dilakukan selama ini belum menunjukkan hasil yang optimal. Korupsi dalam berbagai tingkatan tetap saja banyak terjadi seolah-olah telah menjadi bagian dari kehidupan kita yang bahkan sudah dianggap sebagai hal yang biasa. Jika kondisi ini tetap kita biarkan berlangsung maka cepat atau lambat korupsi akan menghancurkan negeri ini. Oleh karena itu diperlukan upaya luar biasa pula untuk memberantasnya.

Upaya pemberantasan korupsi - yang terdiri dari dua bagian besar, yaitu (1) penindakan, dan (2) pencegahan -tidak akan pernah berhasil optimal jika hanya dilakukan oleh pemerintah saja tanpa melibatkan peran serta masyarakat (Dirjen Dikti, 2011). Penindakan korupsi merupakan bagian kerja dari lembaga penegak hukum di negeri ini, namun upaya pencegahan menjadi tanggung jawab bersama 
unsur-unsur yang ada di masyarakat. Upaya memberantas korupsi yang dianggap efektif dan murah adalah melalui pendidikan.

Bidang pendidikan merupakan salah satu upaya preventif terbaik yang bisa dilakukan. Misalnya melalui Pendidikan Anti Korupsi dan menanamkan nilainilai integritas pada anak sejak dini. Upaya ini diharapkan bisa membentengi generasi muda bangsa ini dari perilaku koruptif sekaligus mencegah lahirnya koruptor-koruptor baru di negeri ini, dan ketika kelak mereka menjadi pemimpin bangsa, mereka akan menjadi yang terdepan yang memperjuangkan kesejahteraan dan kemakmuran Negara.

Salah satu cara untuk menanamkan nilai-nilai pendidikan anti korupsi sebagai bentuk tindakan pencegahan adalah dengan memberikan perhatian khusus terhadap pendidikan anti korupsi sejak dini baik di lembaga pendidikan formal maupun lembaga pendidikan non formal. Pola pendidikan anti korupsi yang integratif diharapkan mampu membuat siswa mengenal lebih dini hal-hal yang berkenaan dengan korupsi dan dampak buruk yang diakibatkan dari tindakan korupsi. Dengan demikian akan tercipta generasi yang sadar dan memahami bahaya korupsi, bentuk-bentuk korupsi dan paham akan sangsi yang akan diterima jika melakukan korupsi. Melalui penelitian yang dilakukan di SMK Al Hidayah Kota Cirebon ini, peneliti merumuskan tiga rumusan masalah yaitu bagaimana pemahaman siswa dan guru Pendidikan Agama Islam di SMK Al-Hidayah Kota Cirebon; bagaimana bentuk, tindakan dan sanksi yang akan diterima jika melakukan korupsi; dan bagaimana pengembangan materi pembelajaran pendidikan anti korupsi melalui Pendidikan Agama Islam di SMK Al-Hidayah Kota Cirebon.

\section{Pengertian Korupsi}

Kata "korupsi” berasal dari bahasa Latin "corruptio" (Fockema Andrea, 1951) atau "corruptus" (Webster Student Dictionary, 1960). Selanjutnya dikatakan bahwa "corruptio" berasal dari kata "corrumpere", suatu bahasa Latin yang lebih tua. Dari bahasa Latin tersebut kemudian dikenal istilah "corruption, 
corrupt” (Inggris), “corruption” (Perancis) dan “corruptie/korruptie” (Belanda). (Pendidikan Anti Korupsi Untuk Perguruan Tinggi, 2011).

Korupsi Dalam Kamus Besar Bahasa Indonesia (KBBI), didefinisikan sebagai "penyelewengan atau penggelapan uang negara atau perusahaan, dan sebagainya untuk keperluan pribadi”. Di Malaysia terdapat peraturan anti korupsi, dipakai kata "resuah" berasal dari bahasa Arab "Risywah" yang artinya sama dengan korupsi. Risywah (suap menyuap) identik dengan memakan barang yang diharamkan oleh Allah SWT. Sedangkan dalam Undang-undang No. 20 tahun 2001 yang dimaksudkan dengan korupsi adalah "Tindakan melanggar hukum dengan maksud memperkaya diri sendiri, orang lain, atau korporasi yang berakibat merugikan keuangan negara atau perekonomian Negara”. Dijelaskan pula dalam Undang-Undang Pemberantasan Tindak Pidana Korupsi Nomor 31 Tahun 1999 pasal 2 ayat 1, korupsi diartikan dengan tindakan memperkaya diri sendiri, memperkaya oeang lain, dan memperkaya korporasi dengan cara melawan hokum dengan merugikan keuangan Negara atau perekonomian Negara.

Korupsi dapat diartikan perbuatan yang buruk seperti penggelapan uang, peneriman uang sogok, dan sebagainya, (Poerwadarminta, 1976 : 524). Sedang dalam Kamus lengkap Bahasa Indonesia Modern yang dikutip oleh Hartanti (2009: 8) korupsi diartikan “ busuk, suka meneima uang suap/uang sogok, memakai kekuasaan untuk kepentingan sendiri dan sebagainya, sedang kata koruptor berarti orang yang melakukan korupsi”.

Jadi secara harfiah korupsi merupakan sesuatu yang yang busuk, jahat dan merusak. Berbicara mengenai korupsi memang akan menemukan kenyataan semacam itu karena korupsi menyangkut segi moral, sifat dan keadaan yang busuk, jabatan dalam instansi atau aparatur pemerintahan, penyelewengan kekuasaan jabatan karena pemberian, faktor ekonomi dan polotik, serta penempatan keluarga atau golongan ke dalam kedinasan di bawah kekuasaan jabatannya (Hartanti, 2009: 8-9).

Gurnar Myrdal dalam bukunya yang berjudul Arisan Darma, menyatakan “ To include not only all forms of improrer or selfish exercise of power and 
influence attached to apublic affice or the special posisition one occupies in the public life but also the activity of the beribers.

Sedangkan unsur-unsur korupsi bisa dikategorikan dalam:

1. Tindakan melawan hukum

2. Menggunakan fasilitas Negara untuk kepentingan pribadi, kelompok, atau golongan

3. Merugikan Negara baik secara langsung maupun tidak langsung

4. Dilakukan oleh pejabat public atau penyelenggara Negara maupun masyarakat (Syarbini dan Arbain, 2014 : 26-27).

\section{Pendidikan Anti Korupsi}

Anti korupsi merupakan sikap tidak setuju, tidak suka, dan tidak senang terhadap tindakan korupsi. Anti korupsi merupakan sikap yang dapat mencegah dan menghilangkan peluang bagi berkembangnya korupsi. Mencegah yang dimaksud adalah upaya meningkatkan kesadaran individu untuk tidak melakukan tindak korupsi dan serta berupaya menyelamatkan uang dan aset Negara. Dengan demikian Pendidikan anti korupsi, merupakan usaha sadar untuk memberi pemahaman dan pencegahan terjadinya perbuatan korupsi yang dilakukan melalui pendidikan formal di sekolah, pendidikan informal pada lingkungan keluarga, dan pendidikan nonformal di masyarakat. Pendidikan antikorupsi tidak berhenti pada pengenalan nilai-nilai antikorupsi saja, akan tetapi, berlanjut pada pemahaman nilai, penghayatan nilai dan pengamalan nilai antikorupsi menjadi kebiasaan hidup sehari-hari.

Dalam menanggulangi bahaya laten dampak dari perbuatan korupsi, wacana pemberantasan korupsi ala Islam perlu di hadirkan. Strategi pemberantasan korupsi ala Islam tersebut antara lain dapat ditempuh melalui cara:

1. Pemberantasan korupsi di Indonesia hanya bisa dijalankan jika hukum dan pelaksanaan hukum dilakukan secara tegas, tegak, adil, dan tidak pandang bulu. Dalam konteks inilah, Al-Qur'an secara tegas memandang penting perlunya penegak hukum (law enforcement) secara adil. 
2. Strategi lain yang diharapkan bisa memberikan kontribusi signifikan terhadap upaya pemberantasan korupsi adalah melalui pemberian hukuman (punishment) yang setimpal dan memberikan efek jera kepada para pelaku korupsi atau pejabat yang berniat melakukan korupsi.

3. Pemberantasan tindak korupsi juga bisa dilakukan melalui jalur pendidikan. Betapapun tengah menghadapi aneka persoalan, pendidikan masih dapat diharapkan menanamkan dan menyebarkan nilai-nilai antikorupsi kepada anak didik sehingga sejak dini mereka memahami bahwa korupsi itu bertentangan dengan norma agama. Untuk itu, upaya pemberantasan korupsi melalui jalur pendidikan dapat dilakukan melalui jalur formal (sekolah/kampus), informal (keluarga), dan non formal (masyarakat) (Syarbini \& Arbain, 2014: 27-35).

\section{Model Pembelajaran}

Model pembelajran merupakan pola umum prilaku pembelajaran untuk mencapai tujuan pembealajarn yang diharapkan. Joyce \& Weil yang dikutip Rusman (2010:139) berpendapat bahwa model pembealajaran adalah suatu rencana atau pola yang dapat digunakan untuk membentuk kurikulum (rencana pembelajaran jangka panjang), merancang bahan-bahan pembelajaran, dan membimbing pembelajaran di kelas atau yang lain. Model pembelajaran dapat dijadikan pola pilihan, artinya para guru boleh memilih model pembelajaran yang sesuai dan efisien untuk mencapai tujuan pendidikannya.

Rusman (2010:139-140) memberikan rambu-rambu kepada pengguna model pembelajaran (guru), agar sebelum menentukan model pembelajaran yang akan digunakan dalam kegiatan pembelajaran harus dipertimbangkan dalam memilihnya, yaitu:

1. Pertimbangan terhadap tujuan yang hendak dicapai.

2. Pertimbangan yang berhubungan dengan bahan atau materi pembelajaran:

3. Pertimbangan dari sudut peserta didik atau siswa

4. Pertimbangan lainnya yang bersifat non teknis: 
Untuk kepentingan penelitian Pengembangan Model Pembelajaran Pendidikan Anti Korupsi, model interaksi sosial yang didasari oleh teori belajar Gestal (field theory), dijadikan sebagai landasan teori yang sesuai dengan materi yang dikembangkan. Sebagaimana yang dikemukakan Rusaman (2010; 143-144), Model pembelajaran ineraksi sosial menitik beratkan hubungan yang harmonis antara individu dengan masyarakat (learning tolife together).

Model Interaksi Sosial ini mencakup strategi pembelajaran sebagai berikut;

1. Kerja Kelompok. Bertujuan mengembangkan ketrampilan berperan serta dalamproses bermasyarakat dengan secara mengembangkan hubungan interpersonal dan discovery skill dalam bidang akademik;

2. Pertemuan Kelas. Bertujuan mengemabngkan pemehaman mengenal diri sendiri dan tanggung jawab, baik terhadap diri sendiri maupun terhadap kelompok;

3. Pemecahan Masalah Sosial atau social inquiry. Bertujuan untuk mengembangkan kemampuan memecahkan masalah sosial dengan cara berpikir logis;

4. Bermain Peran. Bertujuan untuk memberikan kesempatan kepada siswa menemukan nilai-nilai social dan pribadi melalui situasi tiruan;

5. Simulasi Sosial. Bertujuan untuk membantu siswa mengalami berbagai kenyataan sosial serta menguji reaksi mereka.

Pendidikan memberikan bekal pengetahuan, ketrampilan serta nilai-nilai hidup, bekerja dan mencapai perkembangan lebih lanjut di masyarakat. Dengan pendidikan, kita mengharapkan muncul manusia yang lebih bermutu, mengerti dan mampu membangun masyarakatnya. Oleh karenanya diperlukan rancangan model pembelajaran pendidikan anti korupsi yang integratif agar pelaksanaan pendidikan anti korupsi bisa mencapai tujuan dan sasaran yang diharapkan. Penelitian ini akan mengkaji mengenai model pembelajaran pendidikan anti korupsi yang integratif dengan pendidikan agama Islam. SMK Kota Cirebon akan menjadi lokasi penelitian ini. Diharapkan akan dihasilkan model pembelajaran pendidikan anti korupsi yang integratif bagi pendidikan anti korupsi di SMK kota 
Cirebon. Adapun model integratif yang dimaksudkan disini adalah menyisipkan materi anti korupsi ke dalam pelajaran yang sudah ada. Ada 4 (empat) materi pelajaran yang dianggap dekat dengan kajian pendidikan anti korupsi bisa disisipkan yaitu mata pelajaran Pendidikan Agama Islam, Pendidikan Kewarganegaraan (PKn), Pelajaran Sosial (IPS), dan Bahasa Indonesia. Namun yang menjadi fokus penelitian ini adalah mata pelajaran Pendidikan Agama Islam.

Nilai-nilai pendidikan anti korupsi melalui pendidikan agama Islam yang diharapkan dapat membekali siswa dalam kehidupan dalam masyarakat dan menjadi budaya dan menjadi sebuah peradaban. Berikut adalah nilai-nilai pendidikan anti korupsi yang terkandung dalam pendidikan Islam:

1. Jujur

Artinya" Hai orang-orang yang beriman, janganlah kamu mengkhianati Allah dan Rasul (Muhammad) dan (juga) janganlah kamu mengkhianati amanat-amanat yang dipercayakan kepadamu, sedang kamu mengetahui." (QS. Al-Anfal.8: Ayat 27).

2. Tanggung Jawab

Artinya: "Dan kalau Allah menghendaki, niscaya Dia menjadikan kamu satu umat (saja), tetapi Allah menyesatkan siapa yang dikehendaki-Nya dan memberi petunjuk kepada siapa yang dikehendakiNya. Dan sesungguhnya kamu akan ditanya tentang apa yang telah kamu kerjakan" (QS. An-Nahl: 16: 93).

3. Disiplin

Artinya: "Demi masa. Sesungguhnya manusia itu benar-benar dalam kerugian" (QS. Al-Ashr, 103:1-2).

4. Sederhana

Artinya : "(Hai anak Adam, pakailah pakaianmu yang indah) yaitu buat menutupi auratmu (di setiap memasuki mesjid) yaitu di kala hendak melakukan salat dan tawaf (makan dan minumlah) sesukamu (dan janganlah berlebih- 
lebihan. Sesungguhnya Allah tidak menyukai orang yang berlebih-lebihan)" (QS. Al-A'raf. 7: 31).

5. Mandiri

Artinya: "tiap-tiap diri bertanggung jawab atas apa yang diperbuatnya," . (QS. Al- Mudasir, 74: 38).

6. Kerja Keras

Artinya: "Bekerjalah kamu, maka Allah dan Rasul-Nya serta orang-orang mukmin akan melihat pekerjaanmu itu, dan kamu akan dikembalikan kepada (Allah) Yang Mengetahui akan yang ghaib dan yang nyata, lalu diberitakanNya kepada kamu apa yang telah kamu kerjakan” (QS. At-Taubah, 9: 105).

7. Adil

Artinya: "Sesungguhnya Allah menyuruh kamu berlaku adil dan berbuat kebijakan, memberi kepada kamu kerabat, dan Allah melarang dari perbuatan keji, kemungkaran dan permusuhan. Dia memberi pengajaran kepadamu agar kamu dapat mengambil pelajaran” (QS. an-Nahl, 16 : 90)

8. Berani

Artinya". Maka tetaplah kamu pada jalan yang benar, sebagaimana diperintahkan kepadamu dan (juga) orang yang telah taubat beserta kamu dan janganlah kamu melampaui batas. Sesungguhnya Dia Maha melihat apa yang kamu kerjakan" (Q.S.Huud. 11:112)

9. Peduli

Artinya: "Dan tolong-menolonglah kamu dalam (mengerjakan) kebajikan dan takwa, dan jangan tolong-menolong dalam berbuat dosa dan pelanggaran Dan bertaqwalah kamu kepada Allah, sesungguhnya Allah amat berat siksa-Nya" (QS. Al-Ma'idah, 5: 2).

Selanjutnya, dalam beberapa hadis, Rasulullah SAW bersabda yang artinya:

1. "Barangsiapa yang kami pekerjakan pada suatu jabatan, kemudian kami beri gaji, malahan diambilnya selebih dari itu, berarti penipuan" (H.R. Abu Daud). 
2. "Allah SWT melaknat orang yang menyuap, menerima suap, dan yang jadi perantara" (HR. Ahmad Hakim).

3. "Terlaknatlah orang yang disuap dan yang menyuap" (HR. Ahmad).

4. "Jika amanah disia-siakan, maka tunggulah kehancuran Kemudian dinyatakan: "bagaimana maksud amanah disia-siakan itu? Rasul menjawab: "Jika suatu perkara (amanat/ pekerjaan) diserahkan pada orang yang tidak ahli (profesional), maka tunggulah saat kehancuran" (HR. Bukhari) (Syarbini dan Arbain, 2014:12-13).

\section{B. METODE PENELITIAN}

Penelitian ini menggunakan metode kualitatif, dimana dalam penelitian kualitatif, dipelajari segala sesuatu di lingkungannya menurut makna-makna yang diberikan kepada fenomena tersebut. (Denzin dan Lincoln dalam Creswell, 1998).

Subyek dan sumber data dalam penelitian ini adalah Kepala Sekolah, guru bidang Kurikulum, Guru Mata Pelajaran Pendidikan Agama Islam, siswa, TU, dan Dokuman di SMK Al-Hidayah Kota Cirebon.

Dalam penelitian ini teknik yang digunakan dalam pengumpulan data dengan menggunakan: Observasi; Observasi dapat dilakukan terhadap fenomena sosial atau gejala-gejala peristiwa alam dalam kegiatan penelitian lapangan ( Ali, 2007: 62). Wawancara (in depth interview); wawancara adalah percakapan dengan maksud tertentu. Percakapan itu dilakukan oleh dua pihak, yaitu pewawancara (interviewer) yang mengajukan pertanyaan dan terwawawancara (interviewe) yang memberi jawaban (Noeng, 2007:186). Dokumentasi; dokumentasi adalah data dalam penelitian yang diperoleh dari sumber-sumber/ informasi melalui observasi dan wawancara yang berupa buku harian, surat-surat, foto, notulensi rapat, laporan dan lain-lain (Nasution, 2004 : 85). Focus Group Discussion (FGD); FGD sebagai teknik pengumpulan data untuk menemukan makna menurut pemahaman sebuah kelompok berdasarkan hasil diskusi yang berpusat pada permasalahan tertrntu. (Bungin, 2008).

Pada penelitian ini, peneliti menggunakan trianggulasi sember. Menurut Sugiyono (2015:373), trianggulasi sumber adalah menguji kredibilitas data yang 
dilakukan dengan cara mengecek data yang telah diperoleh melalui beberapa sumber. Trianggulasi sumber akan dilakukan pada kepala sekolah, guru PAI dan siswa. Dari berbagai sumber tersebut, kemudian diekspresikan, dikategorisasikan, mana pandangan yang sama, yang berbeda, dan mana yang spesifik dari beberapa sumber data tersebut. Data yang telah dianalisis oleh peneliti sehingga menghasilkan suatu kesimpulan selanjutnya dimintakan kesepakatan (member check) dengan beberapa sumber data tersebut.

\section{HASIL DAN PEMBAHASAN}

Pembelajaran pendidikan agama Islam yang dapat diintegrasikan dengan pendidikan anti korupsi peneliti mengembangkan model pembelajaran pedidikan anti korupsi melalui pendidikan agama Islam dengan menggunakan model pembelajaran Interaksi Sosial.

Model pembelajaran Interaksi Sosial menitik beratkan hubungan yang harmonis antara individu dengan masyarakat (learning to life together). Model pembelajaran ini peneliti gunakan dalam proses pembelajaran Pendidikan Anti Korupsi yang diintegrasikan dengan Pendidikan Agama Islam yang diharapkan bahw melalui model ini dapat memberikan pengetahuan kepada peserta didik bagaimana cara berperilaku dalam kehidupan sebagai mahluk sosial yang berbudi luhur dan menghargai hak-hak orang lain.

Metode yang digunakan dalam proses pembelajaran, peneliti dan guru mencobakan dengan multi metode; seperti bermain peran, pemberian tugas, tanya jawab, dengan harapan setelah mengunakan model pembelajaran interaksi sosial peserta didik dapat memahami dan mempraktekan hasil belajar Pendidikan Agama Islam khususnya yang berkaitan dengan kejujuran dalam kehidupan sehari-hari.

Langkah-langkah yang dilakukan peneliti bersama guru Pendidikan Agama Islam di SMK Al Hidayah Kota Cirebon untuk melaksanakan kegiatan proses pembelajaran adalah; pertama memahami kondisi awal siswa; kedua menentukan materi pendidikan agama Islam yang berkaitan dapat diintegrasikan dengan Pendidikan Anti Korupsi ; ketiga menentukan model pembelajaran; keempat 
melakukan proses pembelajaran; dan yang kelima mengevaluasi kondisi akhir. Berikut tahapan penelitian yang dilakukan peneliti:

\section{Pemahaman Guru Pendidikan Agama Islam terhadap Pendidikan Anti Korupsi.}

Dalam rangka mengetahui pemahaman dan pengetahuan guru agama Islam di SMK Al-Hidayah tentang Pendidikan Anti Korupsi, peneliti telah melakukan wawancara dengan guru bidang kurikulum dan guru Pendidikan Agama Islam. Dalam wawancara tersebut, penulis mengajukan beberapa pertanyaan yang telah disiapkan. Adapun hasil dari wawancara tersebut menghasilkan beberapa poin dibawah ini:

1. Pemahaman terhadap korupsi masih sederhana yaitu penyalahgunaan uang dan waktu. Korupsi menurut guru PAI SMK Al-Hidayah adalah menyalahgunakan dana yang bukan milik pribadi yang merugikan lembaga, negara secara global, dalam pekerjaan juga bisa dianggap korupsi jika bekerja tidak tepat waktu. Guru Pendidikan Agama Islam di SMK Al-Hidayah Cirebon yang berbasis pesantren, telah memahami apa itu pengertian korupsi.

2. Pendidikan Anti Korupsi adalah pendidikan yang antara lain berusaha menanamkan pengertian kejujuran, dan sikap jujur pada anak

3. Unsur-unsur dalam Islam selaras dengan unsur yang tercakup dalam pendidikan anti korupsi. Unsur-unsur tersebut diantaranya adalah bertindak jujur (siddiq). Pokok pangkal korupsi adalah ketidak jujuran (dusta lawan dari sifat siddiq), baik jujur secara administrasi maupun jujur pada diri sendiri, dalam artian walaupun secara administrasi benar, tapi jika benar secara administrasi itu hasil rekayasa, maka hati nurani tidak bisa dibohongi. Itulah yang dimaksud jujur pada diri sendiri. Dalam salah satu Hadits Muhammad Rasulullah menyatakan yang artinya : "Induk dari segala dosa adalah dusta”.

4. Unsur berikutnya dari nilai-nilai anti korupsi adalah amanah (sikap tanggungjawab). Sikap amanah adalah sikap bertangung jawab atas tugas dan wewenang yang dibebankan kepada seseorang. Sikap ini menanamkan nilai anti korupsi dimana jika seseorang mendapatkan tugas dan tangungjawab 
harus ditunaikan dengan sebaik-baiknya terlepas ada yang mengawasi atau pun tidak ada yang mengawasi.

5. Nilai anti korupsi lainnya adalah sikap fathonah (cerdas). Seseorang bisa saja jujur tapi jika kurang cerdas, ia bisa ditipu oleh orang cedas tapi licik. Oleh karena itu orang jujur juga harus cerdas agar tidak ditipu oleh orang cerdas tapi berotak licik.

6. Pendidikan anti korupsi sangat bisa diintegrasikan dengan pendidikan Agama Islam dengan caranya mengemas topik atau sub topik pembelajaran anti korupsi seperti sifat siddiq, amanah, fathonah dan pembudayaan pola hidup sederhana ke dalam rencana dan materi pembelajaran. Pemahaman guru PAI dalam mengintegrasikan pendidikan anti korupsi adalah dengan memilih topiktopik seperti pola hidup sederhana, kejujuran membawa keberuntungan, sifat siddiq, amanah, fathonah, kerja keras, menghindari sikap boros dan pemalas menjadi bagian dari RPP dan materi pelajaran. Dalam pelaksanaan pembelajaran metode yang digunakan menggunakan multi metode dari mulai ceramah, tanya jawab, diskusi, demonstrasi,interaksi social, bermain peran (role play) dan sebagainya.

7. Selain melalui pembelajaran di kelas dan dalam keseharian, nilai-nilai pendidikan anti korupsi juga bisa ditanamkan melalui pembiasaan, yakni pembiasaan bersikap jujur dalam kehidupan sehari-hari siswa, misalnya bersikap jujur ketika ujian kelas dengan tidak mencontek baik dari pekerjaan teman maupun dari buku ataupun internet melalui HP, jujur dalam perniagaan dan lain sebagainya.

8. Adapun terkait implementasi yang diterapkan pada anak didik untuk menanamkan sifat kejujuran. Bentuk pembelajaran lain yang diterapkan pada anak yaitu melalui implementasi kantin kejujuran dimana disaat anak berbelanja di kantin siswa disuruh ambil sendiri makanan yang dikehendaki, kemudian siswa memberitahukan dengan jujur pada ibu penjual makanan berapa makanan yang telah diambil. 
9. Menanamkan sikap takut hanya kepada Allah yang Maha Melihat karena semua perbuatan manusia pasti dilihat oleh Allah SWT dan akan dimintai pertanggungjawaban di hadapan Allah kelak di hari akhir.

10. Pembiasaan lain juga dilakukan misalnya membudayakan bila menemukan sesuatu milik orang lain segera dikembalikan ke pemiliknya atau dilaporkan kepada pihak sekolah.

11. Guru PAI dengan dukungan kepala sekolah, guru lain dan komponen sekolah lainnya berusaha sekuat tenaga menciptakan budaya sekolah yang anti korupsi dengan berbagai cara, misalnya melalui pahala (reward) bagi anak yang jujur dengan diberi hadiah dan hukuman (punishment) bagi yang berbohong, dengan hukuman yang mendidik pula yaitu di antaranya menghafal asmaul husna atau surat pendek dari Al-Qur'an hingga hukuman yang sangat tegas dengan dilaporkan ke polisi atau dikeluarkan dari sekolah.

12. Pihak sekolah juga menyadari tantangan berat dalam menanamkan sikap anti korupsi di kalangan siswa, maka salah satunya adalah dengan memasang CCTV. Fungsi CCTV tersebut adalah untuk memantau perilaku warga sekolah termasuk siswa agar tidak melakukan hal-hal yang tidak terpuji, termasuk melanggar nilai-nilai anti korupsi, misalnya bertindak bohong.

Berdasarkan hasil wawancara diatas, peneliti melihat bahwa guru Pendidikan Agama Islam di SMK Al-Hidayah telah memiliki pemahaman sederhana tentang pengertian korupsi dan pendidikan Anti Korupsi. Pemahaman tersebut juga memperlihatkan keselarasan nilai-nilai Islam dengan nilai pendidikan anti korupsi.

\section{Pemahaman Siswa SMK Al-Hidayah Cirebon terhadap Pendidikan Anti Korupsi.}

Untuk menjawab pertanyaan penelitian pada poin kedua, peneliti untuk melakukan wawancara dengan siswa setelah proses pembelajaran pendidikan agama Islam selesai untuk mendapatkan data tentang pemahaman siswa terhadap pendidikan anti korupsi. Berikut beberapa poin dari hasil wawancara tersebut: 
1. Sumber siswa mendapatkan informasi tentang korupsi berasal dari televisi, buku, guru di sekolah. guru pendidikan agama Islam menurut mereka paling sering menjelaskan tentang korupsi, kejujuran, hemat, disiplin dan sebagainya. Adapun pemahaman korupsi menurut mereka sebatas pada mengambil uang yang bukan hak sendiri.

2. Adapun terkait jenis-jenis tindakan korupsi, siswa SMK Al-Hidayah mengatakan yang termasuk perbuatan korupsi antara lain menggunakan uang masyarakat, nyontek dalam ujian,terlambat masuk sekolah.

3. Siswa pernah melakukan tindakan yang tidak jujur di masa lalu, namun kemudian menyesal. Siswa telah jujur menceritakan pengalaman prilaku dia yang pernah melakukan ketidak jujuran, dan menyadari bahwa perbuatan yang pernah dilakukan ternyata termasuk pada kategori perbuatan korupsi.

4. Guru PAI telah berhasil menanamkan nilai-nilai kejujuran dan berperilaku jujur di kalangan siswa. Indikatornya adalah siswa dapat menjelaskan istilah "korupsi", mempraktikan tindakan kejujuran dalam kehidupan di sekolah dan kesehariannya Keberhasilan tersebut dikarenakan nilai-nilai anti korupsi merupakan nilai utama dalam Islam Pemahaman siswa terhadap pengertian korupsi diperoleh dari buku Pendidikan Agama Islam, bacaan di media massa baik cetak maupun elektronik serta dari penjelasan guru PAI di sekolah.

\section{Pengembangan Model Pembelajaran Pendidikan Anti Korupsi Melalui Pendidikan Agama Islam.}

Dalam pengembangan model pembelajaran Pendidikan Anti Korupsi yang diintegrasikan dengan penedidikan Agama Islam dan Budi Pekerti, sebelum melakukan proses pembelajaran agar mendapatkan hasil yang sesuai dengan tujuan yang akan dicapai, maka ada langkah-langkah yang perlu dilakukan;

Pertama, sebelum model dikembangkan, peneliti beserta guru menentukan topik pembelajaran yang dapat diintegrasikan atau dipadukan dengan pembelajaran Pendidikan Anti Korupsi. 
Langkah kedua, Guru dan peneliti menentukan pendekatan dan metode yang dapat digunakan serta merancang langkah-langkah yang akan di lakukan dalam proses pembelajaran dalam Rencana Pelaksanaan Pembelajaran.

Berdasarkan kajian peneliti terhadap dokumen guru PAI yang berupa Rencana Pelaksanaan Pembelajaran (RPP) yang telah dibuat untuk mata pelajaran Pendidikan Agama Islam dan Budi Pekerti, topik "Kejujuran Membawa Keberuntungan", guru menggunakan model pembelajaran Demonstarsi dengan pendekatan scientific. Namun saat guru mengimplementasikan di dalam kelas metode yang digunakan tidak sesuai dengan apa yang tertulis pada rencana pembelajaran yang telah dibuat, guru masih menggunakan metode konvensional seperti ceramah dan Tanya jawab.

Hasil diskusi peneliti dengan guru PAI, topik yang akan diajarkan "Mempertahankan Kejujuran sebagai Cermin Kepribadian", pendekatan yang digunakan adalah menggunakan pendekatan scientific, model yang digunakan model integrasi, metode yang digunakan dengan menggunakan multi metode yakni; Interkasi Sosial, Role Playing, Diskusi, Ceramah dan Tanya jawab.

Berdasarkan pengamatan selama proses pembelajaran di kelas X Jurusan Teknik Komputer Jaringan, dengan menggunakan multi metode diantaranya adalah metode role playing, diskusi, tanya jawab dan interaksi sosial dalam proses pembelajaran Pendidikan Agama Islam yang dintegrasikan dengan Pendidikan Anti Korupsi dapat diketahui prilaku siswa yang sesuai dengan nilainilai pendidikan anti korupsi terlihat berkembang dengan baik, serta bagaimana semangat, keaktifan dan prilaku siswa semakin meningkat.

Peningkatan prilaku siswa dapat dilihat dari jumlah siswa 43 orang di Kelas X Jurusan Teknik Komputer, peneliti mendapatkan data nilai-nilai pendidikan anti korupsi yang diintegrasikan dengan Pendidikan Agama Islam adalah sebagai berikut:

Tabel 1 Nilai-Nilai Pendidikan Anti Korupsi

\begin{tabular}{|c|c|c|c|}
\hline No & Nilai-Nilai & Siswa & Persentase (\%) \\
\hline 1 & Kejujuran & 36 & 83 \\
\hline
\end{tabular}

Jurnal Edueksos Vol. X, No. 1, Juni 2021

The journal of social and economic education 


\begin{tabular}{|c|c|c|c|}
\hline 2 & Taggungjawab & 40 & 93 \\
\hline 3 & Disiplin & 43 & 100 \\
\hline 4 & Sederhana & 38 & 88 \\
\hline 5 & Mandiri & 35 & 81 \\
\hline 6 & Kerjakeras & 30 & 70 \\
\hline 7 & Adil & 37 & 86 \\
\hline 8 & Berani & 33 & 76 \\
\hline 9 & Peduli & 38 & 88 \\
\hline
\end{tabular}

Berdasarkan pengamatan peneliti selama proses pembelajaran dengan menggunakan motode role playing, dari 43 siswa, 36 siswa atau $83 \%$ telah mengerjakan soal-soal evaluasi yang biberikan oleh guru dengan jujur tanpa melakukan kecurangan seperti menyontek atau bertanya kepada teman atau melalui HP jawaban atas soal yang diberikan.

Untuk prilaku tanggung jawab, hampir $100 \%$ siswa telah melakukan tanggung jawab atas tugas yang diberikan oleh guru, hampir semua siswa melakuakan tugas dengan tepat waktu, dengan hasil pekerjaan cukup baik tidak mengecewakan apa yang diharapkan oleh guru.

Dalam masalah kedisiplinan, dari hasil pengamatan peneliti, seluruh siswa atau $100 \%$ yang menjadi subyek penelitian dalam mengerjakan soal yang diberikan oleh guru menyelesaikan dengan tepat waktu. Hal ini dapat diartikan siswa telah menyadari bahwa menggunakan waktu yang sebaik-baiknya merupakan bekal kesuksesan dalam hidupnya.

Dari jumlah 43 siswa yang telah menunjukkan prilaku sederhana 38 orang atau $88 \%$. Ini menunjukan bahwa siswa telah menyadari prilaku sederhana, tidak sombong, tidak boros merupakan prilaku yang harus diterapkan dalam kehidupan sehari-hari, sehingga tidak terjerumus pada perbuatan - perbuatan yang mubadzir.

Selain nilai-nilai pendidikan sebagaimana yang telah disebutkan di atas, berdasarkan pengamatan, sebagaian besar yaitu 35 atau $81 \%$ dari jumlah siswa 
yang ada telah terlihat kemandirian dalam melakukan kegiatan selama dalam proses pembelajaran seperti mengerjakan soal tanpa meminta banyuan teman.

Prilaku kerja keras siswa juga sudah dapat dilihat pada peyelesaian tugas yang diberikan guru, 30 siswa atau $79 \%$ mereka menyelesaiakannya dengan tepat waktu, meskipun hasilnya belum $100 \%$, ini menunjukan bahwa sebagaian besar siswa telah bekerja keras untuk menyelesaiakan jawaban terhadap soal yang diberikan.

Prilaku adil, berani dan peduli juga telah nampak pada apa yang dilakukan oleh siswa SMK Al-Hidayah, Nilai-nilai pendidikan tersebut berdasarkan pengamatan peneliti jika dilihat dari siwa yang telah melaksankannya jumlahnya hampir sama adil 37 siswa (86\%), berani 33 siswa ( 76\%) dan peduli 38 siswa (88 \%). Dengan pengembangan model integrasi, guru bisa dikatakan telah berhasil menanamkan nilai-nilai pendidikan anti korupsi terhadap siswa, baik pemahaman terhadap teori maupun yang berbentuk prilaku.

Pendidikan Anti Korupsi dalam kurikulum di sekolah tidak secara jelas berbentuk mata pelajaran yang berdiri sendiri. Namun prakteknya untuk penanaman nilai-nilai yang terkandung dalam Pendidikan Anti Korupsi dapat diintegrasikan dengan mata pelajaran - mata pelajaran yang memungkinkan materinya dapat dikembangkan bersama guna penanaman nilai-nilai yang terkandung dalam pendidikan anati korupsi; misalnya Pendidikan agama Islam dan Budi Pekerti.

\section{KESIMPULAN}

1. Korupsi menurut guru PAI SMK Al-Hidayah adalah menyalahgunakan dana yang bukan milik pribadi yang merugikan lembaga, negara secara global, dalam pekerjaan juga bisa dianggap korupsi kalau bekerja tidak tepat waktu.

2. Siswa telah memahami istilah korupsi dalam definisi yang sederhana yang diartikan "mengambil uang atau harta lainnya yang bukan hak sendiri". Selain itu siswa juga dapat memahami dan dapat menunjukkan nilai-nilai anti korupsi yang secara sederhana pula yakni "menggunakan uang masyarakat, nyontek dalam ujian, telat masuk sekolah" dan lain -lain. Siswa juga menyadari pula 
bahwa tindakannya itu salah, dosa besar dan tidak akan mengulanginya lagi. Sebuah sikap kesatriya yang perlu diapresiasi dan diteladani oleh yang lainnya.

3. Materi Pelajaran Pendidikan Agama Islam yang dapat diintegrasikan dengan Pendidikan Anti Korupsi di antaranya adalah topik "Mempertahankan Kejujuran Sebagai Cermin Kepribadian”. dengan Ayat-Ayat Al-Qur'an dan Hadits Tentang Perintah Berlaku Jujur: a). Q.S Al-Maidah, 5:8, b). Q.S. AtTaubah, 9:119. c). Hadits dari Abdullah bin Mas'ud r.a riwayat Muslim tentang kejujuran.

\section{REFERENSI}

Amukowa, Wycliffe \& Samson O.Gungs. 2013. "The Role of Anti-Corruption Education in the Light of Aristotelian Concept of Akrasia: An Epistemic Inquiry into the Anti corruption Initiatives in Kenya". Mediterranean Journal of Social Sciences. Vol 4 No 4.

Ahmadi, Khoiru dan Sofan Amri. 2011. Mengembangkan Pembelajaran IPS Terpadu. Jakarta: Prestasi Pustaka.

Arikunto, Suharsimi. 2001. Manejemen Penelitian. Jakarta: Rineka Cipta.

Burhan, Bungin. 2008. Metodologi penelitian kualitatif. Bandung: CV. Pustaka Setia.

Djaja, Ermanjsah. 2008. Memberantas Korupsi Bersama KPK. Jakarta: Sinar Grafika.

Direktorat Madrasah Kementerian Agama R I, 2013, Panduan Penyelenggaraan Pendidikan Anti Korupsi di Madrasah. Jakarta :

Direktorat Jenderal Pendidikan Tinggi, Kementerian Pendidikan dan Kebudayaan RI. 2011. Buku Pendidikan Anti Korupsi Untuk Perguruan Tinggi. Jakarta.

Elwina, M, 2011, Gerakan, Kerjasama dan Instrumen Internasional. In Pendidikan Anti Korupsi Untuk Perguruan Tinggi (pp. 103-118). Jakarta: Direktorat Jenderal Pendidikan Tinggi Kementerian Pendidikan dan Kebudayaan RI.

Gurning, N. L. 2014. Implementasi Pendidikan Antikorupsi Melalui Warung Kejujuran di SMP Keluarga Kudus. Jurnal Teknologi Pendidikan dan Pembelajaran, Volume 2 No.1

Hakim, L. 2012. Model Integrasi Pendidikan Anti Korupsi melalui Pendidikan Agama Islam. Jurnal Pendidikan Islam-Ta'lim, Volume 10 N0.12.

Hartanti, Evi. 2009. Tindak Pidana Korupsi. Jakarta: Sinar Grafika.

https://aclc.kpk.go.id/materi/pengetahuan-keterampilan-antikorupsi/united-nationsconvention-against-corruption-uncac. 
Idrus, Muhammad, 2009, Metode Penelitian Ilmu Sosial, Pendekatan Kualitatif dan Kuantitatif, Ed.2 Erlangga, Jakarta.

Karsona, A. M. 2011. "Pengertian Korupsi" dalam Pendidikan Anti Korupsi di Perguruan Tinggi (pp. 21-38). DIKTI Kemdikbud RI.

Miles, M.B., and Huberman A.M. 1984. Qualitative Data Analysis. California: Saga Publication.

Moleong, Lexy. 2007. Metode Penelitian Kualitatif. Bandung: PT Remaja Rosdakarya. Bandung.

Nasution, 2004, Sosiologi Pendidikan, PT Bumi Aksara, Jakarta.

Nelty Khaeriyah , Endi Suhendi Zen, 2016, Pendidikan Agama Islam dan Budi Pekerti. Pusat Kurikulum dan Perbukuan, Balitbang, Kemdikbud

Montessari, M. 2012. Pendidikan Anti Korupsi sebagai Pendidikan Karakter di Sekolah. Jurnal Demokrasi (Jurnal Ilmiah Politik Kenegaraan), Volume 11 No.1

Pendidikan Anti Korupsi Untuk Perguruan Tinggi. 2011, Jakarta: Direktorat Jenderal Pendidikan Tinggi Kementerian Pendidikan dan Kebudayaan RI.

Political \& Economic Risk Consultancy, Ltd. (2015). "Perceptions of Corruption in Asia, the US and Australia". Asian Intelligence. No.920. Hongkong: Political \& Economic Risk Consultancy, Ltd.

Poerwandari. 2005. Pendekatan Kualitatif untuk Penelitian Perilaku Manusia. Jakarta: LPSP 3 UI.

Rusman, (2010). Model-Model Pembelajaran, Mulia Mandiri Pers, Bandung

Syadilie, H. Muhsin An, dkk. 2012. Konsep Pendidikan Perspektif Al-Qur'an. Yogyakarta: Spirit.

Syarbini, Amirullah dan Muhammad Arbain. 2014. Pendidikan Anti Korupsi. Bandung: Alfabeta.

Sumiarti. 2007. Pendidikan Anti Korupsi. Jurnal Insania. Volume 12 No.2.

2015. Survei Persepsi Korupsi 2015. Jakarta: Transparency

International Indonesia.

Sugiono. 2015. Metodologi Penelitian Pendidikan. Bandung: Alfabet

Triyanto. 2011. Model Pembelajaran Terpadu. Jakarta: Bumi Aksara

Undang-undang No. 20 tahun 2001 "Tentang Pemberantasan Tindak Pidana Korupsi”

Wibowo, Edi. (2010). Implementasi Good Corporate Governance di Indonesia Jurnal Ekonomi dan Kewirausahaan Vol.10, No.2, Oktober 2010: 129-138)

Wiyono, R. 2009. Pemberantasan Tindak Pidana Korupsi. Jakarta: Sinar Grafika.

Yaqin, N. 2015. Program Pendidikan Antikorupsi di Madrasah. Jurnal Studi Islam Islamuna, Volume 2 No.2, 267-286.

Zuriah, Nurul. 2008. Pendidikan Moral \& Budi Pekerti. Jakarta: Bumi Aksara

Jurnal Edueksos Vol. X, No. 1, Juni 2021

The journal of social and economic education 